\title{
PERAN MAHASISWA DALAM MEMBANTU ADAPTASI TEKNOLOGI TERHADAP GURU PADA PROGRAM KAMPUS MENGAJAR 1 DI SD PELITA BANGSA SURABAYA
}

\author{
Yuli Ayu Ashari ${ }^{1}$, Fajar Setiawan ${ }^{2}$, Lilik Binti Mirnawati ${ }^{3}$ \\ ${ }^{1}$ Universitas Muhammadiyah Surabaya \\ Email: yuli.ayu.ashari-2018@fkip.um-surabaya.ac.id \\ ${ }^{2}$ Universitas Muhammadiyah Surabaya \\ Email: fajarsetiawan@fkip.um-surabaya.ac.id \\ ${ }^{3}$ Universitas Muhammadiyah Surabaya \\ Email: lilikbintimirnawati@fkip.um-surabaya.ac.id
}

\begin{abstract}
Abstrak
Penelitian bertujuan untuk menjelaskan mengenai peran mahasiswa dalam membantu adaptasi teknologi terhadap guru pada program Kampus Mengajar 1 di SD Pelita Bangsa Surabaya. Metode yang digunakan untuk penelitian ini yakni metode kualitatif dengan pendekatan naratif. Penelitian ini mendeskripsikan mengenai peran mahasiswa dalam adaptasi teknologi dalam program kampus mengajar di SD Pelita Bangsa Surabaya dari pengalaman mahasiswa. Hasil penelitian ini dilakukan untuk menjelaskan bahwa peran mahasiswa dapat membantu guru dalam pembelajaran dan administrasi terutama pada adaptasi teknologi terutama dimasa pandemi. Hasil observasi menunujukan bahwa pemanfaatan teknologi yang dilakukan oleh guru belum beragam. Hasil wawancara menunjukkan bahwa mahasiswa sangat membantu dalam adaptasi teknologi karena dapat memperluas pengetahuan mengenai teknologi dan dapat membantu perkembangan sekolah. Hasil dokumentasi menujukkan mahasiswa telah melakukan kegiatan adaptasi teknologi pada saat program Kampus Mengajar. Penelitan ini berdasarkan permasalahan yang dialami guru karena pemahaman mengenai teknologi masih cukup dalam mengoperasikan atau penggunaannya. Hadirnya mahasiswa membantu mengatasi permasalahan dan meberikan solusi yang praktis untuk sekolah terutama untuk guru dalam membuka wawasan baru sekaligus memberikan pengalaman baru kepada mahasiswa.
\end{abstract}

\section{Kata Kunci: Membantu Adaptasi Teknologi, Program Kampus Mengajar}

ABSTRAC

This study aims to explain the role of students in assisting the adaptation of technology to teachers in the Teaching Campus 1 program at Pelita Bangsa Elementary School Surabaya. The method used for this research is a qualitative method with a narrative approach. This study describes the role of students in adapting technology in the campus teaching program at SD Pelita Bangsa Surabaya from student experience. The results of this study were conducted to explain that the role of students can help teachers in learning and administration, especially in adapting technology, especially during the pandemic. The results of observations indicate that the use of technology by teachers has not varied. The results of the interview show that students are very helpful in adapting technology because it can expand knowledge about technology and can help school development. The results of the documentation show that students have carried out technology adaptation activities during the Teaching Campus program. This research is based on the problems experienced by teachers because understanding of technology is still sufficient in operating or using it. The presence of students helps overcome problems and provides practical solutions for schools, especially for teachers in opening new insights while providing new experiences for students.

Keywords: Helping Technology Adaptation, Teaching Campus Program 


\section{Pendahuluan}

Kehidupan yang semakin maju dan berkembang, ditambah kasus wabah Covid-19, dimana aktivitas masyarakat yang dibatasi tidak terkecuali di dunia pendidikan. Sejak diumumkan pemerintah, mengenai kasus pertama Coronavirus disease 2019 (Covid-19) pada bulan Maret yang lalu. Menurut surat edaran nomor 4 tahun 2020 dari kementerian pendidikan dan kebudayaan, mengenai pelaksanaan kebijakan pendidikan dalam masa darurat penyebaran covid-19. Kemudian, disusul dengan surat edaran dari Kementerian Pendidikan nomor 15 tahun 2020 tentang pedoman penyelanggaraan belajar dari rumah dalam masa darurat penyebaran covid-19. Mengenai surat edaran tersebut, menjelaskan tentang kebijakan baru dari kementerian pendidikan dan kebudayaan agar dapat melaksanakan kegiatan pembelajaran secara daring atau online dirumah dalam rangkah mencegah penyebaran virus Covid-19. Oleh karena itu, Kementerian Pendidikan dan Kebudayaan RI, pada tahun 2021 meluncurkan program Kampus Mengajar Angkatan 1. Kebijakan Kampus Mengajar berada dalam kebijakan Merdeka Belajar Kampus Mengajar (MBKM) yaitu memberikan hak belajar tiga semester di luar program studi untuk meningkatkan kopetensi mahasiswa soft skill maupun hard skills agar lebih siap dan relevan degan kebutuhan zaman.

Menurut Kemendikbud (2021:5) menyimpulkan bahwa Kampus mengajar 2021 merupakan program yang dilakukan setelah kampus mengajar perintis pada tahun 2020. Program ini juga didukung oleh Lembaga Pengelolah Dana Pendidikan (LPDP). Kampus mengajar sendiri adalah bagian dari program yang melibatkan mahasiswa di setiap kampus dari berbagai latar belakang pendidikan untuk membantu proses mengajar di sekolah, khususnya pada jenjang SD dan memberikan kesempatan kepada mereka belajar serta mengembangkan diri melalui aktivitas di luar perkuliahan. Menurut Kemendikbud (2021:6) kebijakan kampus mengajar dikeluarkan karena, negeri kita Indonesia sedang membutuhkan bantuan berbagai pihak untuk menyukseskan pendidikan nasional, khususnya di jenjang SD. Mengutip dari Kemendikbud (2021:16) Program kampus mengajar memiliki aktivitas baik mengajar maupun non mengajar harus memperhatikan ramburambu yakni: “(1) Aktivitas mahasiswa lebih bersifat penguatan kompetensi peserta didik dan penumbuhan budaya mutu, (2) Aktivitas pembelajaran tidak menggantikan peran guru, namun 
melengkapi, memperkaya materi dan strategi pembelajaran bagi siswa, (3) Aktivitas mahasiswa ditujukan untuk menginisiasi dan membangun komunitas belajar (Community Development) di sekolah mitra".

Pada penjelasan sebelumnya, mengenai kebijakan dan peraturan dalam kampus mengajar. Maka, kegiatan mahasiswa Kampus Mengajar Angkatan 1 yaitu, berkolaborasi dengan para guru, berkreasi dalam mengajar, serta mendampingi siswa. Pada saat penugasannya, mahasiswa di berikan pembekalan berupa bagaimana cara membuat media pembelajaran, bagaimana membuat suasana pembelajaran yang menyenangkan, dan pembekalan lainnya yang berhubungan dengan kegiatan pembelajaran. Saat kegiatan pun peneliti atau mahasiswa dituntut mengutamakan pembelajaran literasi dan numerasi. Tidak hanya itu, dimasa pandemi ini merupakan tantangan besar untuk para mahasiswa agar dapat memberikan kontribusi dalam kegiatan pembelajaran dengan membantu adaptasi teknologi di sekolah yang menjadi sasaran.

Berdasarkan hasil pengamatan di SD Pelita Bangsa Surabaya pada saat kegiatan Kampus Mengajar Angkatan 1, Khususnya dalam pemanfaatan teknologi. Guru telah menerapkan teknologi dengan Teams, SBOTV, dan WA groub. Pada saat pengamatan tersebut, guru sehari-hari lebih sering menggunakan WA Groub untuk memberikan link evaluasi di Teams. Kemudian, untuk SBOTV digunakan untuk pembelajaran siswa agar memahami materi. Saat penerapan pembelajaran siswa melakukan secara individu. Namun, dalam pelaksanaannya siswa merasa bosan karena masih menggunakan aplikasi yang belum beragam. Pengelolahan administrasi sekolah seperti pengelolahan perpustakaan sekolah juga belum menggunakan teknologi.

Setiawan \& Sukamto (2021:340) menduga bahwa latar belakang dari kegiatan Kampus merdeka atau Kampus Mengajar Angkatan 1 yaitu, Keterbatasan bagi sekolah dasar dari dampak pandemi Covid-19, sehingga perlu solusi praktis dari para mahasiswa untuk membantu sekolah berupa kegiatan operasional, adaptasi teknologi maupun adiministrasi dengan menerjunkan mahasiswa ke sekolah yang terdampak pandemi. Kegiatan Kampus mengajar selain mengutamakan literasi dan numerasi, pembelajaran berbasis IT menjadi tantangan bagi para mahasiswa untuk melakukan pembelajaran dengan menyesuaikan kondisi pandemi saat ini. Sehingga, 
kegiatan yang lakukan untuk adaptasi teknologi tentunya perlu menyesuaikan dengan karakteristik yang di miliki oleh siswa dengan menggunakan teknologi yang sesederhana mungkin. Namun, tetap bertujuan untuk pembelajaran literasi dan numerasi didalamnya.

Mengenai adaptasi teknologi Menurut Diana (2017:3) mengatakan bahwa adaptasi adalah usaha manusia atau makhluk hidup lainnya untuk menyesuaikan diri terhadap lingkungan tertentu dalam menyalanggunakan sumber daya untuk menanggulangi atau menghadapi masalah yang mendesak. Apriliyani, (2019:83) mengungkapkan bahwa teknologi merupakan suatu aplikasi atau penerapan dari ilmu pengetahuan secara praktis guna mempermudah pekerjaan. Maka, dapat disimpulkan bahwa adaptasi teknologi adalah menyesuaikan diri terhadap situasi tertentu untuk mengahadapi suatu masalah menggunakan penerapan dengan ilmu pengetahuan secara praktis misalnnya dengan menggunakan aplikasi.

Adapun tiga penelitian yang relevan dengan judul peneliti. Berdasarkan penelitian yang dilakukan Astini (2020) dalam penelitian yang berjudul "Pemanfaatan Teknologi Informasi dalam Pembelajaran Tingkat Sekolah Dasar Pada Masa Pandemi Covid-19".
Penelitian ini menunjukkan hasil bahwa, pembelajaran perlu melakukan inovasi di masa pandemi dengan melakukan pembelajaran secara online atau daring. Pemanfaatan teknologi informasi menjadi solusi untuk pembelajaran jarak jauh. Kemajuan teknologi informasi yang dapat menghubungkan siswa dan guru melalui laman e-learning, watsapp groub, google class, dan zoom. Adapun yang membedakan penelitian Astini dan penelitian ini dari sudut pandang metodologi adalah penelitian Astini menggunakan penelitian Kualitatif dengan metode Kepustakaan dan metode wawancara. Sedangkan, penelitian ini menggunakan metode penelitian Kualitatif dengan menggunakan pendekatan Naratif. Penelitian Astini menggunakan teknik pengumpulan data kepustakaan dengan instrumen wawancara. Sedangkan, teknik pengumpulan data untuk penelitian ini menggunakan dokumentasi dan observasi dengan instrumen wawancara.

Berdasarkan penelitian kedua, yang dilakukan Anggraeny (2020), dalam penelitian yang berjudul "Analisis Teknologi Pembelajaran Pendidikan Sekolah Dasar" mengenai upaya sekolah untuk melaksanakan pembelajaran dengan menggunakan teknologi. Teknologi yang digunakan disekolah 
tersebut seperti menampilkan gambar, dan film atau video melalui proyektor. Adapun yang membedaan penelitian Anggraeny dan penelitian ini dari sudut pandang metodologi adalah penelitian Anggraeny menggunakan metode deskriptif kualitatif. Penelitian Anggraeny juga menggunakan teknik pengumpulan data dan instrumen dari hasil wawancara. Sedangkan, untuk penelitian ini menggunakan metode penelitian Kualitatif dengan menggunakan pendekatan naratif. Penelitian ini juga menggunakan teknik pengunpulan data berupa observasi dan dokumetasi dengan instrumen wawancara.

Berdasarkan penelitian yang dilakukan oleh Huda (2020), dalam penelitian yang berjudul "Perkembangan Teknologi Informasi dan Komunikasi (TIK) Kualitas Pembelajaran Di Sekolah Dasar". Penelitian ini menunjukkan hasil, bagaimana perkembangan teknologi informasi dan Komunikasi (TIK) dapat mempengaruhi proses pembelajaran di sekolah dasar. Proses pembelajaran akan lebih berkualitas dengan memanfaatkan teknologi informasi dan komunikasi (TIK). Adapun yang membedakan penelitian Huda dan penelitian ini dari sudut pandang metodologi adalah penelitian Huda menggunakan metode penelitian deskriptif kualitatif. Sedangkan, penelitian ini menggunakan metode kualitatif dengan pendekatan naratif. Penelitian Huda menggunakan teknik pengumpulan data dari jurnal-jurnal atau jenis penelitian kajian pustaka serta menggunakan teknik validitas data. Sedangkan, teknik pengumpulan data dalam penelitian ini adalah observasi dan dokumentasi dengan instrumen wawancara.

Berdasarkan pada uraian peneliti diatas, maka penelitian ini bertujuan untuk menjelaskan mengenai peran mahasiswa dalam membantu adaptasi teknologi terhadap guru pada program Kampus Mengajar 1 di SD Pelita Bangsa Surabaya.

\section{METODE PENELITIAN}

Penelitian ini menggunakan jenis penelitian Kualitatif dengan menggunakan pendekatan naratif. Mengutip dari jurnal Jaatshiah, (2021:31) penelitian kualitatif dengan pedekatan naratif merupakan penelitian yang dapat menuliskan mengenai pengalaman dari individu dengan mengacu pada cerita yang didengarkan di dalam aktivitas sehari-hari atau dalam penelitian yang dilakukan. Pada penelitian ini, peneliti mencoba menceritakan kembali mengenai pengalaman penulis saat mengikuti program kampus mengajar angkatan 1. Pada program Kampus 
Mengajar, dimana peran mahasiswa pengumpulan data dan sumber data yang bertujuan agar dapat telah ada yang bersifat teknik memanfaatkan adaptasi teknologi dalam menggabungkan data tersebut. Ada pun pembelajaran di saat masa pandemi. menurut Sofwan (2016:274) mengatakan Peneliti disini, sebagai mahasiswa yang bahwa, triangulasi adalah teknik yang berkesempatan mengikuti program digunakan pada penelitian kualitatif Kampus Mengajar 2021.

Adapun tempat atau lokasi untuk mengecek dan membangun penelitian yaitu di SD Pelita Bangsa Surabaya. lokasi tersebut menjadi lokasi penelitian karena adanya permasalahan sehingga peneliti dapat melakukan penelitian ditempat tersebut. SD Pelita Bangsa menjadi lokasi sasaran di program Kampus Mengajar agar mahasiswa dapat membantu dalam pembelajaran literasi, numerasi, dan dalam adaptasi teknologi dimasa pandemi.

Menyimpulkan dari Naziaha (2020:120) mengatakan bahwa terdapat empat macam teknik pengumpulan data sebagai berikut: (1) observasi merupakan pengamatan dengan mencatat secara sistematis terhadap gejala yang diteliti untuk mengumpulkan data, (2) wawancara adalah mengumpulkan data melalui tanya jawab lisan antara dua orang atau lebih secara langsung, (3) dokumentasi merupakan cara mengumpulkan data dengan mencatat data-data yang sudah ada berupa tulisan, gambar, atau foto, (4) validitas dengan menganalisis data dari berbagai instrumen.

Untuk teknik pengumpulan data yang digunakan untuk penelitian ini yaitu menggunakan teknik observasi, wawancara, dan dokumentasi. Observasi dilakukan untuk mendapatkan data di sekolah tempat penelitian yang di dapat pada saat kegiatan kampus mengajar. Wawancara dilakukan kepada Kepala sekolah, salah satu guru di SD Pelita Bangsa dan mahasiswa yang mengikuti kegiatan program kampus mengajar. Dokumentasi berupa foto kegiatan yang dilakukan pada saat kegiatan kampus mengajar untuk menguatkan data penelitian. Kemudian, teknik triangulasi data digunakan untuk mengecek atau melihat validitas data dengan menganalisis data diatas. Triangulasi untuk penelitian ini menggunakan triangulasi data. Indikator pengukuran pemanfaatan teknologi Menurut Zubaidi (2020:70) menyatakan bahwa kemampuan manusia dalam penggunaan teknologi memiliki indikator gabungan triangulasi merupakan pengukuran yaitu jumlah komputer yang 47 | Peran Mahasiswa Dalam Membantu Adaptasi Teknologi .......... 
memadai, dapat memanfaatkan jaringan internet dengan baik, dan penggunaan software atau perangkat lunak sesuai dengan peraturan undang-undang. Indikator diatas, yang akan digunakan peneliti untuk menyusun instrumen.

Ada pun teknik analisis data penelitian kualitatif. Menurut Rijali (2019:83) bahwa proses analisis data penelitian kualitatif menggunakan 4 tahapan. Pertama, pengumpulan data adalah berkaitan dengan teknik untuk menggali data atau informasi di tempat yang diteliti. Kedua, reduksi data adalah proses untuk memilih, menyederhanakan kata yang didapat setelah kegiatan pengumpulan data. Ketiga, penyajian data merupakan kegiatan menyusun informasi selama di tempat penelitian sehingga memungkinkan untuk penarikan kesimpulan. Keempat, penarikan kesimpulan merupakan kegiatan untuk peneliti untuk menarik kesimpulan secara terus-menenerus dengan mendeskripsikan gambaran dari objek yang diteliti agar lebih jelas.

\section{HASIL DAN PEMBAHASAN}

\section{Hasil Penelitian}

Hasil penelitian ini dilakukan untuk menjelaskan bahwa peran mahasiswa dapat membantu guru dalam pembelajaran dan administrasi terutama pada adaptasi teknologi terutama dimasa pandemi. Berdasarkan penelitian ini sekolah termasuk di dalamnya yaitu tenaga pengajar perlu bantuan dalam adaptasi teknologi, untuk mendapatkan data informasi maka peneliti identifikasi dengan melakukan observasi, wawancara, dan dokumentasi. Tahapan observasi dan dokumentasi telah dilakukan pada saat kegiatan Kampus Mengajar Angkatan 1.

Hasil Observasi, menunujukan bahwa pemanfaatan teknologi yang dilakukan oleh guru belum beragam. Kopetensi guru dalam mengoperasikan teknologi dalam pembelajaran masih dirasa cukup bagus akan tetapi dalam adaptasi teknologi guru tetap memperhatikan perkembangan IT. Observasi didapat peneliti saat melengkapi laporan awal dalam kegiatan Kampus Mengajar Angkatan 1 di SD Pelita Bangsa Surabaya. Untuk kendala yang dihadapi siswa pada saat proses pebelajaran secara garis besar yaitu siswa tidak memiliki handpone sendiri.

Hasil wawancara yang dilakukan kepada kepala sekolah, guru, dan mahasiswa. wawancara kepada kepala sekolah yang berinisial DN peran mahasiswa dalam adaptasi teknologi berpengaruh besar terhadap guru untuk lebih mengetahui pembelajaran berbasis IT yang lebih beragaram. Kemudian, Wawancara kepada guru yang berinisial 
$\mathrm{R}$ yang merupakan wali kelas 6 dan sekaligus guru pamong pada saat mahasiswa Kampus Mengajar Angkatan 1 di SD Pelita Bangsa. Pada saat wawancara guru $\mathrm{R}$ mengatakan bahwa mahasiswa sangat membantu dalam adaptasi teknologi karena dapat memperluas pengetahuan mengenai teknologi dan dapat membantu perkembangan sekolah. Wawancara kepada mahasiswa yang berinisial CAA kegiatan yang dilakukan pada saat kampus mengajar 1 yang telah dilakukan untuk membantu sekaligus memperkenalkan beberapa aplikasi yang dapat membantu guru dalam kegiatan pembelajaran maupun administrasi di sekolah.

Hasil dokumentasi yang pada saat mahasiswa membantu adaptasi teknologi terhadap guru. Kegiatan berupa penerapakan dan mengenalkan teknologi yang dapat digunakan dalam pembelajaran maupun untuk administarasi sekolah.

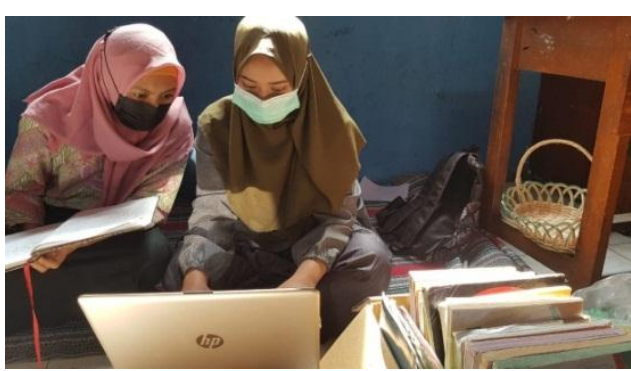

Gambar 1. membantu administrasi perpustakaan dari berbentuk buku memindahkan kedalam bentuk Ms. Excel.

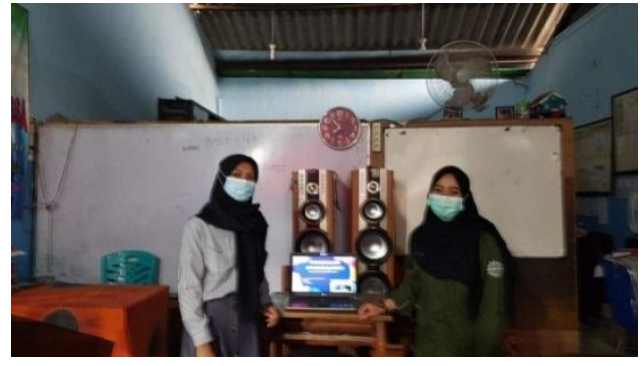

Gambar 2. Menerapkan sekaligus memperkenalkan aplikasi Quziz untuk evaluasi siswa.

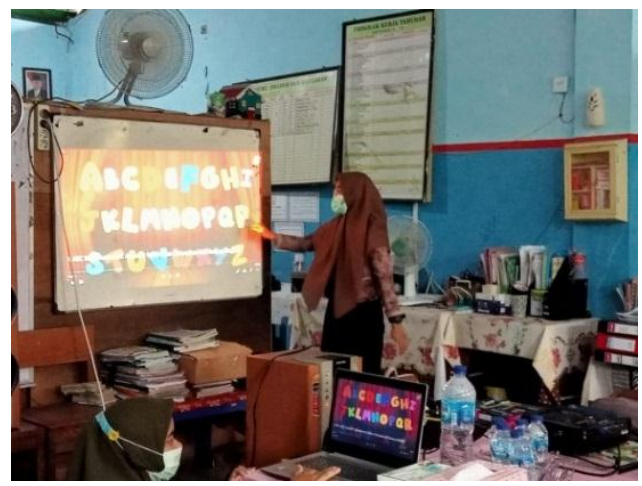

Gambar 3. Pembelajaran dengan video animasi.

\section{Pembahasan}

Kegiatan mahasiswa dalam membantu adaptasi teknologi terhadap guru pada saat kegiatan kampus megajar di SD Pelita Bangsa Surabaya berkaitan dengan proses pembelajaran yang saat ini mengikuti kebiasaan baru yang lebih banyak menggunakan sistem daring atau online. Sebelumnya, teknologi pada dunia pendidikan menjadi sebuah media penunjang dalam kegiatan pembelajaran disekolah sekaligus sebagai pengetahuan dasar di tingkat sekolah dasar. Pada perubahan sistem pendidikan saat ini membuat masalah baru yang akan dihadapi sekolah terutama para guru yang berkaitan 
dengan kompetensi dalam penggunaan teknologi untuk pelaksanaan kegiatan belajar-mengajar.

\section{Menurut Fitria (2019:15)} mengatakan bahwa kompetensi guru memiliki standart meliputi 4 kompetensi utama yakni, kompetensi pedagogik, kompetensi kepribadian, dan kompetensi sosiial, dan kompetensi profisional. Menurut Farla (2021:140) menjelaskan pengertian dari keempat kompetensi utama guru sebagai berikut: Pertama, kompetensi pedagogik adalah kemampuan guru dalam mengelolah, melaksananakan, mengevaluasi, dan pengembangan peserta didik dengan mengembangkan kurikulum pembelajaran dengan memanfaatkan teknologi informasi dalam pembelajaran. Kedua, kompetensi keperibadian merupakan kemampuan guru dalam bertindak sesuai dengan norma agama, hukum, sosial, dan memiliki etos kerja yang tinggi dan menampilkan pribadi yang teladan untuk peserta didik. Ketiga, kompetensi sosial adalah kemampuan guru dalam beradaptasi dengan lingkungan kerjanya dan berkomunikasi dan berinteraksi baik dengan peserta didik. Keempat, kompetensi profesional adalah kemampuan gruru dalam mengembangkan dan menguasai materi pembelajaran secara kreatif, serta pemanfaatan teknologi informasi dan komunikasi. Keempat kompetensi tersebut perlu dimiliki oleh seorang pendidik untuk mengelolah sekolah maupun dalam melaksanakan pembelajaran.

Oleh sebab itu, hadirnya mahasiswa dalam program kampus mengajar bermaksud untuk memberikan bantuan kepada sekolah yang memiliki dampak pandemi untuk berkolaborasi kepada guru, dan membantu administrasi sekolah. Bantuan yang diberikan mahasiswa disesuaikan dengan keperluaan atau permasalahan yang ada disekolah. Adapun kegiatan yang harus dilakukan mahasiswa dalam kegiatan Kampus Mengajar yaitu literasi, numerasi, dan adaptasi teknologi.

Pembelajaran juga tak lepas dengan adanya media yang akan digunakan dalam proses pembelajaran. Hanafi \& Nurhasanah (2017:188) mengatakan bahwa Media adalah sebuah alat yang digunakan dalam menyajikan pesan dan merangsang siswa untuk belajar. Adapun menurut Mirnawati (2020:264) media pembelajaran adalah alat bantu yang digunakan guru untuk menyampaikan materi pembelajaran kepada siswa. Berdasarkan data hasil wawancara kepada kepala sekolah, guru, dan mahasiswa saat peneliti melakukan penelitian. Mahasiswa memanfaatkan 
media yang memadai yang digunakan untuk kegiatan adaptasi teknologi yang digunakan oleh mahasiswa selama program kampus mengajar 1. Media yang digunakan oleh mahasiswa dalam kegiatan adaptasi teknoloogi antara lain: laptop, Handphone, dan Proyektor. Kegiatan yang dilakukan oleh mahasiswa Kampus Mengajar Angkatan 1 dilakukan berdasarkan permasalahan yang dialami sekolah dalam adaptasi teknologi dalam kegiatan pembelajaran maupun administasi sekolah.

Media tersebut untuk kegiatan pembelajaran daring maupun luring yang dilakukan disekolah. Peneliti bersama rekan yang berinisial $C$ melakukan kegiatan di kelas 5 siswa yang berjumlah 9 siswa. kegiatan dilakukan tetap menaati protokol kesehatan tetap mencuci tangan, menjaga jarak dan memakai masker. Adapun yang mendasari mahasiswa melakukan penerapan adaptasi teknologi misalnya dalam penggunaan aplikasi Quiziz dan google form untuk memperkenalkan aplikasi ini yang dapat digunakan untuk mengukur kemampuan siswa dan manfaat terhadap guru yaitu, kegiatan pembelajaran menjadi lebih beragam. Kemudian, adaptasi untuk administrasi sekolah berawal dari data buku yang digunakan masih dalam bentuk buku sehingga dapat mudah rusak dan hilang. Maka, mahasiswa menggunakan ms. Excel dalam adaptasi teknologi. sehingga dalam kegiatan Kampus Mengajar Angkatan 1 yang dilaksanakan selama 3 bulan yang dilakukan oleh mahasiswa berdampak pada adaptasi teknologi terhada guru di sekolah SD Pelita Bangsa Surabaya.

Dokumentasi yang telah dilakukan mahasiswa pada program Kampus Mengajar Angkatan 1 mahasiswa membantu adapatasi teknologi terhadap guru melalui penggunaan Quiziz, Google Form, video animasi, YouTube untuk pembelajaran dan Penggunaan Ms. Excel untuk membantu administasi perpustakaan.

\section{KESIMPULAN}

Berdasarkan hasil paparan diatas, penelitian ini membahas mengenai peran mahasiswa dalam membantu adaptasi teknologi terhadap guru di Program Kampus Mengajar Angkatan 1 di SD Pelita Bangsa Surabaya. Penelitan ini berdasarkan permasalahan yang dialami guru karena pemahaman mengenai teknologi masih cukup dalam mengoperasikannya atau penggunaan sehingga siswa sering merasa bosan saat kegiatan pembelajaran karena belum beragam. Melalui adaptasi teknologi yang beragam berupa penerapan aplikasi Quiziz, Google form, 
video animasi, YouTube dan Ms. Excel dalam membuka wawasan baru mahasiswa dapat membantu mengatasi permasalahan. sekaligus memberikan pengalaman baru kepada mahasiswa.

Memeberikan solusi yang praktis untuk sekolah terutama untuk guru

\section{DAFTAR PUSTAKA}

Anggraeny, D., Nurlaili, D. A., \& Mufidah, R. A. (2020). Analisis Teknologi Pembelajaran dalam Pendidikan Sekolah Dasar. Fondatia, 4(1), 150-157. https://doi.org/10.36088/fondatia.v4i1.467

Apriliyani, T., Siswoyo, M., \& Supriyadi, A. (2019). Analisis Kompetensi Pegawai Dalam Pendokumentasian Arsip Melalui Teknologi Komputer Di Dinas Lingkungan Hidup Kota Cirebon. Jurnal IImiah Publika, 7(2), 1-7.

Astini, Sari, N. K. (2020). Pemanfaatan Teknologi Informasi dalam Pembelajaran Tingkat Sekolah Dasar pada Masa Pandemi Covid-19. Jurnal Lembaga Penjaminan Mutu STKIP Agama Hindu Amlapura, 11(2), 13-25.

Farla, W., Nailis, W., \& Siregar, L. D. (2021). Peningkatan Kompetensi Sumber Daya Manusia ( SDM ) Guru di Kota Palembang Pada Era Adaptasi Kebiasaan Baru. 4(April), 137-142.

Fitria, H., Kristiawan, M., \& Rahmat, N. (2019). Upaya Meningkatkan Kompetensi Guru Melalui Pelatihan Penelitian Tindakan Kelas. Abdimas Unwahas, 4(1), 1425. https://doi.org/10.31942/abd.v4i1.2690

Hanafi, H., \& Nurhasanah, E. (2017). Penggunaan Multimedia Pembelajaran Berbasis Tutorial. 187-192.

Huda, I. A. (2020). Perkembangan Teknologi Informasi Dan Komunikasi (Tik) Terhadap Kualitas Pembelajaran Di Sekolah Dasar. Jurnal Pendidikan dan Konseling (JPDK), 2(1), 121-125. https://doi.org/10.31004/jpdk.v1i2.622

Jaatshiah, A. T. (2021). Pembelajaran Jarak Jauh Bagi Anak Hambatan Intelektual Pada Masa Pandemi Covid-19. Jurnal Penelitian Pendidikan Khusus, 9(1), 97104. http://ejournal.unp.ac.id/index.php/jupekhu/article/view/111542

Kemendikbud. (2021). Program Kampus Mengajar 2021. 6.

Mesra Diana. (2017). Strategi Adaptasi Mahasiswa Kristen Di Universitas Islam Negeri Sultan Syarif Kasim Riau. Jom Fisip, 4(2), 1-15.

Mirnawati, L. B., Izzah, W., \& Hamidah, F. (2020). Literasi Dalam Pendidikan di Era Digital Untuk Generasi Milenial Bahan Ajar Digital Dalam Materi Pembelajaran Literasi Dalam Pendidikan di Era Digital Untuk Generasi Milenial. 1-10. 
Naziaha, S. T., Maula, L. H., \& Sutisnawati, A. (2020). Analisis Keaktifan Belajar Siswa Selama Pembelajaran Daring Pada Masa Covid-19 Di Sekolah Dasar. Jurnal Paedagogy: Jurnal Penelitian dan Pengembangan Pendidikan, 7(2), 109-120.

Rijali, A. (2019). Analisis Data Kualitatif (Qualitative Data Analysis). Alhadharah: Jurnal Ilmu Dakwah, 17(33), 81.

Setiawan, F., \& Sukamto. (2021). Fakultas Keguruan dan IImu Pendidikan Universitas Riau Alamat: Program Studi PGSD FKIP Universitas Riau. Pendidikan Guru Sekolah Dasar, 10, 263484.

Sofwan, M., Jambi, U., Habibi, A., \& Jambi, U. (2016). Problematika Dunia Pendidikan Islam Abad 21 Dan Tantangan Pondok Pesantren Di Jambi. Problematika Dunia Pendidikan Islam Abad 21 Dan Tantangan Pondok Pesantren Di Jambi, 46(2), 271-280. https://doi.org/10.21831/jk.v46i2.9942

Zubaidi, N., Cahyono, D., \& Maharani, A. (2020). Pengaruh Kompetensi Sumber Daya Manusia, Pemanfaatan Teknologi Informasi dan Kualitas Laporan Keuangan terhadap Kualitas Laporan Keuangan. Jurnal IImiah Akuntansi Kesatuan, 8(2), 137-146. https://doi.org/10.37641/jiakes.v8i2.372 